\title{
The impact of Zimbabwe's constitutionalisation of local governance on strengthening citizen participation and good governance
}

\author{
Anesu Mironga*, Christopher Namilonga** \\ ${ }^{*}$ College of Business, Peace, Leadership and Governance, Africa University \\ ** * College of Business, Peace, Leadership and Governance, Africa University \\ DOI: 10.29322/IJSRP.11.10.2021.p11841 \\ http://dx.doi.org/10.29322/IJSRP.11.10.2021.p11841
}

\begin{abstract}
From the inception of the independence of Zimbabwe in 1980 to May 2013, the Lancaster House Constitution was governing Zimbabwe. This document was basically regarded as a negotiated document which provided for the transition to black majority rule from the white colonialism. The Lancaster House Constitution was subsequently criticized for failing to meet the standards of contemporary democratic ideas and practices. The major political parties of the Government of National Unity (GNU) conducted a disputed constitution-making process that resulted in the 2013 Zimbabwe Constitution. In local governance the new constitution was hailed as ushering in a new era. The effects of the provisions of Zimbabwe's 2013 Constitution on strengthening citizen participation and good governance was critically examined in this research. Contrary to the provisions of the constitution, the central government has not given local governance powers to the people to enhance good governance and citizen participation. Local government legislative matters not aligned with the Constitution, as well as the central government's lack of political will, are cited in this article as reasons for delays in the implementation of the Constitution's provisions on local governance.
\end{abstract}

Index Terms - Citizen Participation, Constitutionalisation, Local Governance, 2013 Constitution of Zimbabwe

\section{INTRODUCTION}

This paper is anchored on the notion that the Constitution of Zimbabwe of 2013 guides and speaks to local governance in Zimbabwe. It addresses the importance of the constitution in enhancing citizen participation, public involvement and good governance, as well as the goals of Zimbabwe's 2013 Constitution in reorganizing local government. It examines the events on the ground in light of the Constitution's local government provisions, and provides an analysis of citizen participation and good governance as championed in the Zimbabwe's constitution of 2013.

The paper begins by conceptualizing local governance, citizen participation and good governance before delving into the implications of the 2013 Constitution detailing the provisions that speak to local governance. The last section gives an analytic lens in the assessment of levels of compliance to good governance and citizen participation and closes with recommendations on the way forward.

\section{CLARIFYING KEY CONCEPTS}

Central to a good conceptual evaluation of the impact of constitutionalisation on citizen participation and good governance is an indepth understanding of the key concepts involved. This section makes provision for the definitions of the key terms which are fundamental to this paper. Three terms are local governance, citizen participation and good governance. Besides these three concepts, other concepts will be explained where they are used for the first time.

\section{A. Local Governance}

Shah \& Shah (2006) define local government as specialized units and institutions formed by national constitutions (Italy, India, Japan, Denmark, Brazil, France), by state constitutions (USA, Australia), by a higher tier of central government ordinary legislation (most countries, United Kingdom, New Zealand) or through an executive order (China) to render an array of specified service to a comparatively small geographically demarcated and delineated area.

Local government, according to Chakaipa (2010), is a democratically constituted and tasked echelon of government that consists of legal units with specified establishments, entrusted with authority over a specific territory within the national legislation-imposed 
restrictions, and is largely self-financing. According to Musingafi (2012), local government is the construction of a constitutionally and democratically elected and participatory structure that is able to relate to the demands of the people on a local level and guarantees that those requirements are converted to real provisioning, maintenance and sustainability of critical infrastructure and services. Local governments act as a conduit for central government policy and the delivery of public services and goods to the public (Mapuva, 2015). Murimoga and Musingafi (2014) view local government as the formation of a lower tier of governance that has the mandate of carrying out duties and services that the central government is far removed to execute, local government has the potential to respond to and better articulate the needs of the locals because it is the realm of government that is most accessible to the general public. Murimoga and Musingafi (2014) further state that local government is in a better position to connect both local efforts and knowledge when carrying out its mandate. According to Chikerema (2013) as a decentralisation dimension, local government is an outcome of devolution. In Zimbabwe, local government is given powers that have a direct impact on the lives of the people in the community (Murimoga \& Musingafi, 2014).

Local governance is an important component and level of government in every country, it requires proper investment to enable sustainable growth and responsible governance anchored by active public participation in decision-making and high-quality service delivery. Local government is closest to the people in terms of governance structures, organizations, and processes that take place in the immediate area of inhabitants and citizens (Nkomo, 2017). According to Sikander (2015), a municipal or local government is not an authority that is sovereign, it has nothing to do with taxation, security and defense, foreign trade or bank rates, but it serves as the representative body by making the surrounding areas conducive for habitation, the provision of education for children, ensuring cleanliness of the streets, construct houses and facilitate the provision of a civilized life to the inhabitants. All these things makes local government an agent for change (Sikander, 2015).

Jordan (1984) claims that local government dates from the 1890s in Zimbabwe, when the British South African Company (BSAC) arrived and instituted the first local authority, the Salisbury Sanitary Board. In Zimbabwe, local government has never been an autonomous area and has always been governed by legislation. The Ministry of Local Government and Public Works (MLGPW) is in charge of the two components of local government law: the Urban Councils Act (1996) and the Rural District Councils Act (1996). The MLGPW directs the activities of local government organisations and bodies and this makes them extensions of the central government (Zimbabwe Institute, 2005). The Traditional Leaders Act (2000), the Regional Town and Country Planning Act, and the Provincial Councils and Administration Act (1985) are also administered by the MLGPW. At the centre of local government in Zimbabwe are these five pieces of legislature and these define the functions, powers, structures and procedures (Chatiza, 2010)

\section{B. Citizen Participation}

The term of citizen engagement has been used in local governance discourse for the past two decades. In this article, a citizen is a person who lives in a municipality. Prabakaran (2011) states that citizens are citizens only if they have the right to exercise constitutional provisions that the state provides, the absence of rights reduces citizens to mere subjects. It is articulated that the reduction of citizens to subjects is a sign of bad governance and elevating subjects to citizens is good governance (Prabakaran, 2011). Citizen participation and engagement is an important and desired aspect of community development, and it should be incorporated into the policy-making process. Citizen participation is increasingly being embraced by policy making and implementation institution.

Contemporarily, the term "participation" has a broad meaning associated with or involved in some activity (André, Martin, \& Lanmafankpotin, 2012). According to Beach (1996), people give ideas to the solving of problems that affect their organization through participation. The American Council on Development (2006) defines participation as an individual's or a community's involvement in all stages of development and decision-making.

Citizen engagement entails citizens actively participating in and engaging in government-related activities. (Langton , 1978). Citizen participation is explained by Fox and Meyer (1995) as "the involvement of citizens in a wide range of activities that relate to the making and implementation of policy including the determination of level of service, budget priorities and the acceptability of infrastructure projects in order to orient government programs towards community needs, build support and encourage a sense of cohesiveness within society". Citizen participation, according to Cunningham (1972), is defined by three key elements: first, ordinary individuals who are community members with no recognized source of power other than their numbers, second, persons who use their authority to influence their group to think and act in specific ways, and third, decisions comprising significant and major affluent options. Arnstein's Ladder of Citizen Participation, according to Mapuva (2010), depicts the presence of three types of citizen participation: non-participation, tokenism, and citizen empowerment. Mapuva (2010) goes on to say that non-participation is a circumstance in which the government manipulates the system by executing initiatives without the public' consent. Tokenism as Arnstein states, the government makes an effort to consult the people and listen to their problems and give promises and hope that they will be looked into. In citizen empowerment, the decision making has been decentralized by government and the citizens have been accorded the sovereignty to make enlightened choices that benefit their communities, Arnstein refers to this level as citizen power (Mapuva, 2010). More citizens can be sure that their thoughts and views will be incorporated in decision-making and used in the best interests of their society as they move up the ladder (Arnstein, 1969).

\section{Good governance}

This publication is licensed under Creative Commons Attribution CC BY.

http://dx.doi.org/10.29322/IJSRP.11.10.2021.p11841

WWW.ijsrp.org 
In contemporary times, the terms good governance and governance have progressively been used in the development discourse. This section of conceptual analysis will first look at governance then good governance.

As a concept, governance may be traced back to the dawn of human society. To put it simply it "is the process of decision making and the process by which decisions are implemented or not implemented" (United Nations, 2018). It is generally accepted that governance is not a new notion, but rather one that has existed since the dawn of human civilisation. Governance is derived from the Greek term kybernan, which means "to rule" or "to steer or pilot a ship." During the Roman Empire, the notion was also known as gubenare, which means to guide, rule, or direct. The term "gouvernance" was most likely adopted by the English from the French word "gouvernance," which dates from the 12th century. The notion of governance has evolved through time, and it is now primarily defined as the interaction of commercial stakeholders, governments, and non-profit organizations that results in policy decisions (Ysa, Albareda, \& Forberger, 2014) Governance involves the processes and stages by which a government carries out its functions, it is the relationship between society and its rulers (Momoh, 2015). The management of resources and policy formulation through the exercise of authority and power is referred to as governance; It refers to the means and mechanisms by which various political actors utilize their legal rights in order to attain economic, social, cultural, and political goals (Caluser \& Salagean , 2007). The term "governance" refers to a complex mix of public and private activities and institutions that are commonly linked with administration. The Commission on Global Governance (1995) defines governance as

The sum of the many ways individuals and institutions, public and private manage their common affairs. It is a continuing process through which conflicting or interests may be accommodated and interests' cooperative action may be taken. It includes formal institutions and regimes empowered to enforce compliance as well as informal arrangements that people and institutions either have agreed to or perceived to be in their interest (CGC, 2007)

In the governance arena, government is one of the players. Non-state actors (NSAs) are additional players and these include financial institutions, religious leaders, political parties, the military and non-governmental organisations (NGOs), , moreover to these at national level the media, international donors, lobbyists and multi-national corporations (MNCs) have influence in the decision-making processes (United Nations, 2018). Corporate governance, global governance, local governance, and international governance are a some of the situations where governance can be applied (United Nations, 2018).

Good governance is a concept that emerged due to bad governance which is characterised by the unaccountability of governments and institutions, corruption as well as a violation of human rights, and these had become increasingly dangerous, necessitating immediate intervention (Caluser \& Salagean , 2007). According to Alcroft (2015) good governance as a concept rose to prominence in the 1900s with the development of a formula for improving governments' capacity and efficiency in delivering services (Aly, 2013). The exercise of authority through institutional and political processes that are accountable, transparent and encourage public participation is referred to as good governance (United Nations, 2007). Good governance, according to Transparency International, is the exercise of political power and control by a society, as well as the social and economic growth of its resources, with accountability, citizen participation, transparency, an enabling judicial/legal framework, combating corruption and responsiveness as key elements. (TIZ, 2020).

According to Wyman (2007) good governance addresses these issues:

Universal protection of human rights, non-discriminatory laws, efficient, impartial and rapid judicial processes, transparent public agencies, accountability of decisions by public officers, devolution of resources and decision making to local levels from the capital, meaningful participation by citizens in debating public policies and choices (Wyman, 2007)

According to the United Nations (2018), "the eight characteristics of good governance are participatory, consensus-oriented, accountable, responsive, inclusive, efficient and effective, equitable and inclusive, transparent, and commitment to the rule of law". Fundamentally, good governance principles encompass various ideals for a better society (Caluser \& Salagean , 2007). Government and governance are linked. Institutions provide the money and laws and public employees produce services, while government determines the experience that citizens get when they deal with officers who deliver the required service (Rose \& Pfeiffer, 2018). These outputs are the "good" benefits of public policy such as health care and education and the not so welcome but necessary services such as fines and court orders.

\section{The 2013 CONSTITUTION AND IMPLICATIONS FOR LOCAL GOVERNANCE}

The 2013 Constitution of Zimbabwe was a product of broad participation from stakeholders and it received $95 \%$ approval vote in the Referendum that was held on 16 March 2013 with high expectation of implementation (Chatiza, 2017). A constitution is a set of fundamental principles and precedents that govern the recognition and administration of a state or other institution, according to the Oxford Dictionary. Kersting, Caulfield, Nickson, Olowu and Wollmann, (2009) describe a constitution as a higher law that regulates how governments and institutions work, as well as people's rights and political power.. It is a legislative instrument that defines, organizes, and distributes state power and governance (Mukoyi, 2020). As stated by Bulmer (2017), the great majority of modern

This publication is licensed under Creative Commons Attribution CC BY.

http://dx.doi.org/10.29322/IJSRP.11.10.2021.p11841

WWW.ijsrp.org 
constitutions outline the state's essential concepts and procedures and the structure of government, as well as citizens' fundamental rights, a constitution is a higher law that cannot be amended arbitrarily by a regular legislative act. Wekwete (2017) describes a constitution as defining the key parameters including definitions of obligations and rights of the citizen, the organisations of the different branches of the state, that is the executive, legislative, judiciary and local government. Constitutionalisation refers to the endeavour to subject all government acts in a given field to the constitution's processes, principles, values, and structure. It is a term used to describe the attempt to subject the exercise of all types of public power, regardless of the channel or means through which it is exercised to the constraints of constitutional norms and procedures (Loughlin, 2010). Constitutionalisation is a way of evaluating the substance, form and legitimacy of a constitution (Lakvin, 2010).

Wekwete (2017) purports that the 2013 Constitution of Zimbabwe was an upshot of compromise between the Government of National Unity's (GNU) two main parties that is the Movement of Democratic Change (MDC) and Zimbabwe African National Union - Patriotic Front (ZANU-PF). In terms of proclaiming the values of democracy the Constitution was welcomed as an accomplishment, politically it was not welcomed as an accomplishment by either of the political parties and was seen as a means to an end as it was a principal stipulation on the holding of elections in July 2013, elections where ZANU-PF won and reaffirmed their domination in the management of the state (Wekwete, 2017). Zimbabwe's 2013 Constitution, according to Chigwata and De Visser (2018), recognizes local government as the lowest unit of government in a three-tier framework and local government now exists as a result of the Constitution rather than law, as was previously the case. The constitution's promise of local government, as established in Chapter 14 and other sections, was jeopardized, raising the fundamental question of what difference the constitution can make to local administration (Wekwete, 2017). This section makes reference to the whole 2013 Constitution of Zimbabwe with implications on local government and not just Chapter 14.

Local government constitutionalisation is anchored in Chapter 14 of Zimbabwe's 2013 Constitution. The Constitution's Preamble reads "the need to entrench democracy, good, transparent and accountable governance, commitment to upholding and defending human rights and freedoms" (Chatiza, 2017). Section 3:2(1) acknowledges devolution and decentralisation of state functions and powers as a principle of good governance and this lays the foundation for Chapter 14 on local government, metropolitan councils and provincial councils, and Chapter 15 on traditional leadership. The Preamble to Chapter 14 states "the democratic participation in government for all citizens and communities must be guaranteed" (Wekwete, 2017). Section 5 of Zimbabwe's 2013 Constitution defines provincial - metropolitan councils and local authorities as tiers of government, implying that councils represent and administer the affairs of people in urban and rural areas, respectively. Chatiza (2017) agrees that this provision sets the basis of Sections 274:1 and 275:1 which give councils power to govern. Sections 274:1 and Section 275:1 acknowledge and reinforce the existence of rural and urban local authorities to manage and represent the affairs of the people (Wekwete, 2017). The national vision of a prosperous, flourishing, free, just, and democratic society in which individuals live rich, happy, and satisfying lives is described in Section 8:1, and this section according to Chatiza (2017) gives prominence to the purpose of governance. Chapter 9 elaborates on good governance by outlining public administration principles at all levels of government.

In the provision of separate spaces and mechanisms for the distribution of power and responsibilities between the State and various citizen platforms that advance the citizen's freedom to assemble and associate (Section 58) taking direct part in their development (Section 13) and freedom to demonstrate and petition (Section 59) the Constitution sets the transformative outline for the governance of Zimbabwe (Chatiza, 2017). This is premised in Section 62:1 which state that citizens should be provided "...right of access to any information held by the state." This is built on the Preamble's reference to "...Recognizing the need to entrench democracy, good, transparent and accountable governance and the rule of law, Reaffirming our commitment to upholding and defending fundamental human rights and freedoms." These provisions of the constitution are critical as they present reason for a system of governance that is devolved in relation to the definition and pursuance of strategies that focus on the attainment of national vision (Section 8 and objectives (Section 13).

The Zimbabwean Constitution of 2013 places the responsibility of ensuring citizen involvement on the state. Section 13:2 directs State institutions to "involve the people in the formulation and implementation of development programs that affect them". Section 17:1 mentions specific categories and groups (Gender equality and women's participation in all aspects of life), 21:2(a) and 2(d) the elderly's participation and the promotion of social organizations aimed at improving their quality of life. Section 20:1b and 3 looks at youth association, representation and participation in all spheres of life and Section 22:1 and 3d focusses on treating people with physical and mental disabilities with respect and dignity (Chatiza, 2017)

The 2013 Constitution of Zimbabwe accords the opportunity for citizens to recast citizen-citizen and state-citizen relationships by changing the local government ownership structure and culture (IRI, 2015).

\section{A. The Constitution and Citizen Participation}

The term citizen participation appeared in the USA in the 1950's and 1960's in the United States of America in the context of antipoverty programs and urban renewal (Gauvin \& Abelson, 2006). According to Langton (1978), citizen participation in local government policymaking and implementation can provide benefits such as diverse perspectives on particular issues, as well as a sense of ownership of projects and a sense of civic pride. He goes on to say that this can help to prevent abuse and misuse of administrative authority and political power. According to Mapuva (2010) citizen participation in local governance provides every citizen with the option to participate in deliberations that would result in all-encompassing institutional decisions; through participation, private individuals are given the ability to influence public decisions.

This publication is licensed under Creative Commons Attribution CC BY

http://dx.doi.org/10.29322/IJSRP.11.10.2021.p11841

WWW.ijsrp.org 


\section{Citizen Participation and the Electoral Process}

Citizens can express their ideas and opinions at the local level in a variety of ways, including through the electoral process. Elections are important in reinforcing decentralised governance and deciding on the type and nature of officials who will occupy municipal and public posts to a greater extent (Chikerema, 2013). Muriisa (2007) amplifies this notion by adding that the local government system and citizens can communicate their wants and acquire access to resources through elected leaders, while bureaucracy is decreased, resulting in enhanced efficiency. According to Braun and Grote (2000), elected leaders are more responsive to citizens' needs, are responsible, and participate in decision-making. The 2013 Constitution of Zimbabwe plays a pivotal role in the amplification and engagement of citizen voices. As enshrined in the Constitution in Section 139 (f) and Section 141 (a)(b) and (c) and in particular Section 141 (a) and (b) which says "...facilitate public involvement in its legislative and other processes and in the process of its committees..."

\section{Citizen Participation and Participatory Budgeting}

The budget, according to Doer (1998), is a description of expected revenue and budgeted expenses for a fiscal term. A budget, described by Nkala (2004), is a tool for determining how fiscal resources should be allocated and how public goods and services should be provided in the public sector. Citizens should be involved in their communities' budget processes so that people can communicate their needs and guarantee that monetary resources are spent appropriately (Chikerema, 2013).

Participatory budgeting is a democratic decision-making and discussion process whereby the ordinary citizen determines the allocation or part of the municipal budget (Chikerema, 2013). Chikerema (2013) further highlights that it is comprised of the identification of expenditure priorities and also to represent various communities and the implementation of community projects that have a direct impact on the local citizens.

According to Zimbabwe's Local Government Act (2006), to allow citizens to analyze and criticize the budget plans, they must be published in three issues of the newspaper. Corresponding to the Zimbabwe's Urban Councils Act (2006), participatory budgeting is part of a larger strategic effort to improve democracy in local governments, as well as transparency and accountability in public funds management and budgeting, to promote civic participation and interest, local government and community participation in the creation of self-sustaining livelihoods (Chikerema, 2013)

\section{Public Hearings and Consultative Forums}

In the case of Zimbabwe's local governance system, consultative forums and public hearing have a way of ensuring that participation is encouraged (Chatiza, 2017). Section 141 (b) of the 2013 Constitution of Zimbabwe says "...ensure that interested parties are consulted about Bills being considered by Parliament, unless such consultation is inappropriate or impracticable..." Consultative Forums and Public Hearings are meant to be a permanent part of the local government's legislative process and this allows citizens to freely engage with their local authorities, and this situation is guaranteed by the constitution (ERC, 2016).

\section{B. The Constitution and Good Governance}

Zimbabwe's 2013 constitution includes many clauses relating to good administration (TIZ, 2020). The Preamble to the Constitution and the Founding Values establish the tone for ethical government and anti-corruption efforts, "...Zimbabwe is built on the respect for the following values and principles: (h) good governance." The constitution's founding beliefs and principles are outlined in Section 3 I. The 2013 Constitution Preamble states that "...we the people of Zimbabwe...recognizing the need to entrench democracy, good transparent and accountable governance and the rule of law...resolve by the tenets of the Constitution to commit ourselves to build a united, just and prosperous nation founded on values of transparency, equality, freedom, honesty and dignity of hard work". Section 9 provides a mechanism that safeguards the accountability and integrity of public officials. According to the clause, all government agencies and organizations at all levels must create and execute policies and laws to increase efficiency, accountability, personal integrity, competency, and financial probity (TIZ, 2020).

Section 9 of the constitution establishes procedures to ensure public officials' integrity and accountability. It specifies that all government institutions and agencies at all levels as well as all public institutions, shall develop and implement policies and laws to promote efficiency, competency, accountability, transparency, personal integrity, and financial integrity (TIZ, 2020).

\section{AsSESSing LeVEls OF COMPLIANCE: EVENTS ON THE GROUND}

While the 2013 Constitution of Zimbabwe has made provisions for citizen participation and good governance in local governance in Zimbabwe, events, actions and the situation on the ground shows that they are delays in implementation. The adoption of Zimbabwe's 2013 Constitution was not accompanied by a related alignment of various government elements (Mapuva \& Takabika, 2020), as summarized by Mapuva (2015), this resulted in confusion, contradictions, overlap, and duplication of functions. Since the adoption in 2013, Zimbabwe has slowly introduced reforms to ensure constitutionality of legal institutes, their implementation and their adoption into practise and the input from the citizens leaves a lot to be desired, consultations have been done in a piecemeal manner leading to half-baked pieces of legislation that does not reverberate with the ambitions and desires of the citizens (ERC, 2016). The greatest impediment since the constitution came into being in 2013 is the political will needed to chart all the required legislation to make the local government system work. As Wekwete (2017) posits, the pressure of the power-sharing GNU which birthed the Constitution has diminished leaving ZANU-PF to take its time to implement the various chapters of the constitution. 
Despite all of the positive aspects of citizen participation, its implementation has a few stumbling blocks, including the rise of cynicism toward leaders and voter turnout in general. According to some scholars, the limitations of representative government are becoming more obvious (Rosenvallen, 2008). Citizen participation has been linked to various drawbacks, such as being time consuming, slow, and costly, and having the potential to elicit a negative reaction if citizens' inputs are ignored (Fox \& Meyer, 1995). McEwan (2005) amplifies that the effects of policies based on citizen engagement can produce ambiguous results and in some ways may lead to new forms of govermentality. Participatory practices may possibly strengthen the outspoken few while marginalizing society's poor (McEwan, 2005). According to André, Martin, and Lanmafankpotin (2012), public participation policies should not be viewed as a panacea for overcoming democratic inadequacies; rather, focus should be made on forms of political engagement that exist outside of official settings where citizens can express themselves.

A democratic, devolved local government system is a long-term goal, and there is a need for long-term capacity building programs aimed at citizens and local governments, voter apathy and low turnout at elections can be a thing of the part as the citizens become more and more engaged

Several governance and corruption indices, such as the Ibrahim Index of African Governance (IIAG) and the Transparency International Corruption Perceptions Index (CPI), show how pervasive corruption and bad governance have become in Zimbabwe. Experts, business leaders and professionals rate and rank countries depending on how corrupt their public sector is regarded to be corrupt as perceived by experts and business executives. For the past five years, Zimbabwe has lagged behind the sub-Saharan regional average (2015-2019) (TIZ, 2020). Corruption erodes public officials' accountability, diminishes the openness of state institutions' operations, and permits human rights violations to go unpunished. Corruption leads to the channeling of government resources and funds away from providing public goods and services and it subdues economic growth (Aly, 2013). It obstructs the fulfilment of basic rights and diverts funds intended for local development and social services. Corruption jeopardizes the government's ability to provide health, education, and welfare services. Corruption has a greater impact on the poor and marginalized, who rely heavily on public services (United Nations, 2007)

Zimbabwe is well tenanted with civic organisations that have registered to work with residents, and civil society acts as the state's watchdog and act as a conduit for the transmission of civic voices to the government, they are also expected to take part in civic education and empower citizens to claim their voices in governance issues, however their voices are suppressed and an ear is not given (ERC, 2016)

Citizen participation in national and municipal budget consultative meetings is now more crucial as economies are shrinking due to COVID-19 and the deficits have to be funded by the citizens themselves as they will be no options of borrowing (New Zimbabwe, 2021). Maropa (2021) highlighted that there is a misconception that municipal budgets were for the well up people and were motivated by the elite sentiments. Makumbe (2021) added to this by saying that the participation of women in these pre-budget and budget meetings has been hindered by the misconception that that financial debates are for men, most women have been raised in patriarchal societies and believe that bold meetings to do with finance are the domain of men. Zimbabwe Coalition on Debt and Development (ZIMCODD) conducted a study in Zimbabwe on open budget in 2019 which showed that $57,3 \%$ of the citizens have never taken part in pre-budget consultative meeting while 56,1\% do not believe that their contributions to these sessions will be adopted (New Zimbabwe, 2021). Further to this, the report also unveiled that participation was 52, $27 \%$ for males and 35, 04\% for women. Citizens also fail to participate due to ignorance and misconceptions and view these meetings as political (Mapuvire, 2021). Mapuvire (2021) further stated that citizens are always in the election mode even when elections are past, people shun the budget meeting because they think the leaders are inclined to a certain political party and those who attend even politicize these meeting (Mapuvire, 2021). When citizens begin to depoliticize local governance or national issues only when can there be a sunnier and brighter picture ahead

According to the World Bank (2001) citizen involvement and participation in municipal and local government "creates a vicious cycle that ensures that the majority needs are heard and helps increase the voice of the poor in local affairs". It is argued that although in some local authorities in Zimbabwe citizens are given the chance to participate in local politics, their recommendations and input have not been always adopted or implemented (Madzimure, 2021). For citizen participation to be effective, the local government and the central government must be accountable to the citizens

\section{RECOMMENDATIONS AND WAY FORWARD}

The Urban Councils Act and the Rural Councils Act must be aligned with Zimbabwe's 2013 Constitution in order to achieve good governance in the current local governance system. The legislature of local government should offer residents and citizens a platform to engage and participate in the affairs of the local authority and citizens should have the power to hold elected officials accountable.

There is need for meaningful devolution, local governments must be granted more autonomy by the central government. Freeing the local authorities will enhance wider innovation, responsiveness, adaptation and increased citizen participation. It will also enhance flexibility (Nyikadzino, 2020)

Decentralisation is the most effective way of limiting the extreme concentration of power at the center, this is one of Zimbabwe's present governance model's distinctive features, and which is incompatible with the fundamentals of good governance, such as probity, openness, fairness, and transparency.

Participation in crucial meetings that handle critical issues such as budgets, housing, water and waste management should be afforded to citizens, the feedback of citizens is critical in ensuring that local government officials are aware of how they are functioning in terms

This publication is licensed under Creative Commons Attribution CC BY.

http://dx.doi.org/10.29322/IJSRP.11.10.2021.p11841

WWW.ijsrp.org 
of service delivery. Councilors should be compelled to have report back meetings regularly with the citizens to bridge the gap in communication and enhance accountability, transparency and citizen participation.

Of paramount importance is the role of associations that represent the interests of the residents to be continuously active in raising consciousness on issues that affect the citizenry. These organizations serve a critical role in the distribution of information and education to the general public on their rights as enshrined by the 2013 Constitution. The Constitution also guarantees the right to information in Section 62 .

To curb the rent-seeking activities and corruption, watchdog institutions should be empowered. Government should give watchdog institutions prosecution and sanctioning authority. Prosecution and conviction of corrupt local authority officials will send a strong message to those willing to engage in corruption (Dube, 2019)

\section{CONCLUSION}

The role of the 2013 Constitution of Zimbabwe in strengthening citizen participation and good governance was documented in these pages. The article set out to examine in what way constitutionalisation of local governance has strengthened citizen participation and good governance. The main conclusion that can be drawn from the analysis is that while the constitution has made these provision for citizen participation and good governance, events on the ground portray a different scenario. It is evidenced that the lack of political will is standing in the way of decentralization of the country's local government system.

\section{REFERENCES}

[1] ACPD. (2006). Strengthening citizen participation in local decision making. Cape Town, South Africa.: Fingerprint Cooperative Ltd.

[2] Aldcroft, D. (2015). Governance, Institutions and Corruption: Negative Sovereignty in Africa. In R. N. Ghosh, \& M. B. Siddique, Corruption, Good Governance and Economic Development: Contemporary Analysis and Case Studies (pp. 63-83). London: World Scientific.

[3] Aly, W. O. (2013). Bad Governance and Failure of Development Progress in Egypt Causes, Consequences and Remedies. Journal of Public Administration and Governance, 39-60.

[4] André, P., Martin, P., \& Lanmafankpotin, G. (2012). Citizen Participation. In L. Côté , \& J. F. Savard, Encylcopedic Dictionary of Public Administration (pp. 1-4). Canada: Library and Archives Canada, www.dictionnaire.enap.ca.

[5] Arnstein, S. R. (1969). A Ladder of Citizen Participation. Journal of American Institute of Planners, 35(4), $216-224$.

[6] Beach, D. (1996). Personnel : the Management of People at Work. New York : Macmillan Publishing Co.

[7] Braun, V. J., \& Grote. ( 2000). Does Decentralisation serve the poor? IMF Conference on Fiscal Decentralisation (pp. 20-21 November). Washington DC: IMF.

[8] Bulmer, E. (2017). What is a Constitution? Principles and Concepts. Stockholm: International Institute for Democracy and Electoral Assistance.

[9] Caluser, M., \& Salagean, M. (2007). Good Governance in Multiethnic Communities. South East Europe: Ethnocultural Diversity Resource Center.

[10] CGC. (2007). Our Global Neighbourhood . http://www.itcilo.it/english/actrav/telearn/global/ilo/globe/gove.htm: Commission on Global Governance.

[11] Chatiza, K. (2010). Can local government steer socio-economic transformation in Zimbabwe? Analysing historical trends and gazing into the future. In J. de Visser, N. Steytler , \& N. Machingauta, Local government dialogue in Zimbabwe: A policy reform (pp. 1-25). Bellville: Community Law Centre.

[12] Chatiza, K. (2017). Introduction. In K. H. Wekwete, \& G. Munro, Strengthening Capacity for Local Governance and Service Delivery in Zimbabwe Project (pp. 3 7). Harare: European Union.

[13] Chigwata, T. C., \& De Visser, J. (2018). Local government in the 2013 constitution of Zimbabwe: Defining the boundaries of local autonomy. Hague Journal on the Rule of Law, 10(1), $154-185$.

[14] Chikerema, A. F. (2013). Citizen Participation and Local Democracy in Zimbabwean Local Government System. Journal Of Humanities And Social Science, 13(2), 87-90.

[15] Cunningham, J. V. (1972). Citizen Participation in Public Affairs. Public Administration Review, vol. 32, Special Issue: Curriculum Essays on Citizens, Politics, and Administration in Urban Neighborhoods, 589-602.

[16] Doer, J. E. (1998). Dictionary of Public Administration. Kualar Lumpur: Golden Books Centre.

[17] Dube, C. (2019). MAIN BOTTLENECKS AT THE LOCAL AUTHORITY LEVEL THAT COULD POSE CHALLENGES FOR GROWTH AND SUSTAINABILITY. Harare: Zimbabwe Economic Policy Analysis and Research Unit.

[18] ERC. (2016). Enhancing Citizen Voices and participation in electoral policy. Harare: Election Resource Centre.

[19] Fox, \& Meyer. (1995). Public and Development Management. Bellville: University of Stellenbosch.

[20] Gauvin, F. P., \& Abelson, J. (2006). Primer on Public Involvement. Canada: Health Council of Canada.

[21] Ingham, B., \& Kalama, A. K. (1992). Decentralisation and development: Theory and evidence from Bangladesh. Public Administration and Development .

[22] IRI. (2015). Survey on Local Governance \& Constitutionalism. Washington DC: International Republican Institute.

[23] Jordan, J. D. (1984). Local Government in Zimbabwe: An Overview. Gweru: Mambo Press.

[24] Kersting, N., Caulfield, J., Nickson, R. A., Olowu, D., \& Wollmann, H. (2009). Local governance reform in global perspective (Vol. 12). . Verlag: Springer.

[25] Lakvin, D. (2010). Concept of Constitutionalism. Researchgate.

[26] Langton, S. (1978). Citizen participation in America. Massachusetts:: Lexington.

[27] Loughlin, M. (2010). What is Constitutionalism. In P. Dobner, \& M. Loughlin, The Twilight of Constitutionalism. Oxford Scholarship: Oxford.

[28] Madzimure, T. M. (2021). A Case for Decentralization in Zimbabwe's Local Government System: Challenges and Opportunities. Archives of Business Research, $9(2), 1-21$.

[29] Makumbe, P. (2021, January 25). Citizen Participation In Pre-Budget Meetings More CrucialPost Covid-19. New Zimbabwe, p. 1.

[30] Mapuva, J. (2010). Citizen Participation and democracy: Safeguarding citizen participation through the Government of Natioal Unity (GNU) or democracy violated. Journal of Public Administration 45(1), 30-42.

[31] Mapuva, J. (2015). The controversies of devolution in Zimbabwe. International Journal of Political Science and Development, 3(5), $183-192$.

[32] Mapuva, J., \& Takabika, T. (2020). Urban local authorities in Zimbabwe and the new. International Journal of Peace and Development, 11(1), 1-8.

This publication is licensed under Creative Commons Attribution CC BY.

http://dx.doi.org/10.29322/IJSRP.11.10.2021.p11841

WWW.ijsrp.org 
[33] Mapuvire, S. (2021, 25 January). Citizen Participation In Pre-Budget Meetings More CrucialPost Covid-19. Retrieved from New Zimbabwe.

[34] Maropa , C. (2021, January 25). Citizen Participation In Pre-Budget Meetings More CrucialPost Covid-19. New Zimbabwe, p. 1.

[35] McEwan, C. (2005). New Spaces of Citizenship? Rethinking Gendered Participation and Empowerment in South Africa,", vol. 24, no. 8, pp. . Political Geography, 24(8), 969-991.

[36] Momoh, Z. (2015). Corruption and Governance in Africa. The International Academic Conference for Sub-Sahara African Transformation \& Development. Ilorin Kwara State Nigeria: University of Ilorin, 1000 Capacity Lecture Theatre Hall.

[37] Mukoyi, J., 2020. Chapter 14 of the Constitution and Implementation of Devolution in Zimbabwe. International Journal of Scientific and Research Publications, 10 (11), pp. 999-1005.

[38] Muriisa, R. C. (2007). NGOs and Rural Development in Uganda, MPhil thesis. Norway: University of Bergen.

[39] Murimoga, R., \& Musingafi, M. C. (2014). Local goverance and service delivery in Zimbabwean local authorities: The case of Harare and Masvingo. Int. Journal of Public Policy and Admin Research, 1(3), 94-107.

[40] New Zimbabwe. (2021, January 25). Citizen Participation In Pre-Budget Meetings More CrucialPost Covid-19. New Zimbabwe, p. 1.

[41] Nkala, P. (2004). The social Sector and the National Budget. A centre on Social Welfare,Education, Agriculture and the Informal Sector in Zimbabwe. Bulawayo: A paper prepared for the budget process workshop at Holiday Inn Bulawayo.

[42] Nkomo, D. (2017, February 17). Challenges of local governance in Zimbabwe. Retrieved from Zimbabwe Today: http://zimbabwe-today

[43] Nyikadzino, T. (2020). The devolution of governmental powers and responsibilities in post-independent Zimbabwe (Doctoral Thesis). Johannesburg: Univeristy of Johannesburg.

[44] Oxford Dictionary. (2021, March 2). Oxford Disctionary. Retrieved from https://www.oed.com/

[45] Prabakaran, M. (2011, March 20). What is Good Governance? Retrieved from Researchgate: https://www.researchgate.net/publication/228123335_What_is_Good_Governance

[46] Rose, R., \& Peiffer, C. (2018). Bad Governance and corruption. London: Palgrave Macmillan.

[47] Sikander, T. (2015). A Theoretical Framework of Local Government. International Journal of Humanities and Social Science, 5(6), $171-176$.

[48] TIZ. (2020). Endemic corruption in Zimbabwe: Is the Constitution ofZimbabwe Amendment (No.20) Act 2013 failing us? Harare: Tranparency International Zimbabwe.

[49] United Nations. (2018). What is good governance. United Nations Economic and Social Commission for Asia and the Pacific.

[50] Wekwete, K. H. (2017). Chapter 2: Constitutionalism and Local Government in Zimbabwe. In K. H. Wekwete, \& G. Munro, Strengthening Capacity for Local Governance and Service Delivery in Zimbabwe Project (pp. 8-14). Harare: European Union.

[51] World Bank. (2001). World development report 2000/2001: Attacking poverty. Washington DC: World Bank.

[52] Wyman, M. (2007). Thinking about Governance: A Draft Discussion Paper Prepared for. The Commonwealth Foundation Citizens and Governance.

[53] Ysa, T., Albareda, A., \& Forberger, S. (2014). Governance of addictions in Europe. Oxford: Oxford University Press.

[54] Zimbabwe Institute. (2005). Local Government: Policy Review. Cape Town: Zimbabwe Institute.

\section{AUTHORS}

First Author - Anesu Mironga, PhD Student, Africa University, mirongaa@ africau.edu

Second Author - Christopher Namilonga, PhD Student, Africa University, namilongac@africau.edu

Correspondence Author - Anesu Mironga, mirongaa@ africau.edu , mironga.anesu@gmail.com, +263772389362. 